\title{
Studies on Gypsophila fastigiata parameters verifying its suitability to reclamation of post-flotation $\mathrm{Zn}-\mathrm{Pb}$ wastes
}

\author{
Ewa Muszyńska ${ }^{1}$ Ewa Hanus-Fajerska ${ }^{1}$, Krystyna Ciarkowska ${ }^{2}$ \\ ${ }^{1}$ University of Agriculture in Krakow, Institute of Plant Biology and Biotechnology, Unit of Botany and Plant Physiology; \\ al. 29 Listopada 54, 31-425 Krakow, Poland; e-mail: emuszynska@ogr.ur.krakow.pl (corresponding author) \\ ${ }^{2}$ University of Agriculture in Krakow, Faculty of Agriculture and Economics, Soil Science and Soil Protection Department; \\ al. Mickiewicza 21, 31-120 Krakow, Poland
}

(C) 2015 Authors. This is an open access publication, which can be used, distributed and reproduced in any medium according to the Creative Commons CC-BY 4.0 License requiring that the original work has been properly cited.

Received: 29 November 2014; accepted: 21 April 2015

\begin{abstract}
An excessive amount of heavy metals negatively affects the environment, causing degradation of large areas throughout the world. Therefore, the effective and inexpensive techniques focused on either removal of those substances or their long-term stabilization in situ need to be improved. We currently propose to use a calamine ecotype of Gypsophila fastigiata (Caryophyllaceae) for biological reclamation of wastes accumulated after $\mathrm{Zn}-\mathrm{Pb}$ ores enrichment. Plants were cultivated in (1) untreated waste material (control), (2) wastes enriched with mineral fertilizers, and (3) wastes enriched with sewage sludge. Photosynthetic pigments content and electrolyte leakage outside plasma membrane were tested periodically in representative samples. In untreated waste material growth gradually deteriorated during the season. The content of chlorophyll $a$ in leaves taken from control plants decreased more than threefold from $0.51 \mathrm{mg} / \mathrm{g}$ f.m. at the beginning to $0.14 \mathrm{mg} / \mathrm{g}$ f.m. at the end of the growing season, whereas in treatment with sewage sludge the reduced seasonal variations in photosynthetic pigments content was ascertained $(0.78 \mathrm{mg} / \mathrm{g}$ f.m. for $\mathrm{chl} a$ and $0.20 \mathrm{mg} / \mathrm{g} \mathrm{f.m.} \mathrm{for} \mathrm{chl} b$, both in the spring and autumn) what positively influenced the plant growth. The results indicate that tested $G$. fastigiata genotype might be used in an assisted revegetation project.
\end{abstract}

Keywords: calamine waste, heavy metal, sewage sludge, NPK, plant growth, photosynthetic pigments, electrolyte leakage

\section{INTRODUCTION}

In the south-west part of Poland large quantity of wastes have been accumulated, especially in areas of lead-zinc ore exploitation. Deposited waste material is strongly contaminated with zinc, lead and cadmium. Tailings ponds of post-flotation material create serious environmental problem because of their contamination or dispersion of contaminants to the adjacent areas and ground waters (Szarek-Łukszewska \& Grodzińska 2008, Cabała et al. 2009b, Ospina-Alvarez et al. 2014). Thus, only through establishment of a dense vegetation cover, a desirable surface stability and a reduction of erosion rate can be achieved (Tordoff et al. 2000, Cabała et al. 2009a, Panagos et al. 2015). However, numerous plant growth-limiting factors like deficiency of substances essential for proper growth, the presence of toxic metals, high insolation, strong wind, drought, or unfavorable $\mathrm{pH}$ value, eliminates many plants species from this area (Przedpełska \& Wierzbicka 2007, Janecka \& Sobik-Sołtysek 2009, Ravi et al. 2012). Due to before mentioned reasons the biological reclamation of metalliferous wastes is an uneasy and time-consuming task. Special attention is currently paid on 
native plants species that spontaneously invade mine wastes (Szarek-Łukaszewska 2009, Muszyńska et al. 2013, Singh et al. 2015), and locally occurring populations are considered to be much more resistant to harsh conditions in comparison to other plant material. Consequently, they can be used for reclamation purposes (Testiati et al. 2013, Zhang et al. 2014). Another useful approach is application of different amendments to promote plants growth in order to stabilize wastes without delay and as a result the mobility of pollutants. For example, organic additives like different agro- or industrial wastes, plant extracts, exudates, and humic substances have been tested as either possible source of heavy metals chelators or plant development biostimulants (Halim et al. 2003, Lamichhane et al. 2012, Soriano-Disla et al. 2014).

Species Gypsophila fastigiata, belonging to Caryophyllaceae family, is growing spontaneously on mine wastes near Bukowno (southern Poland) as local ecotype ecologically adapted to this unfavorable growing conditions (Szarek-Łukaszewska \& Grodzińska 2008). Therefore experiments were undertaken in order to (1) test suitability of Gypsophila fastigiata for restoration of such degraded area, and (2) optimize conditions for growth and development of plant specimens by selecting favorable additives to waste material. Herewith, we were particularly interested in growth rate and selected physiological parameters of tested plant material.

\section{METHODS}

\section{Plant material and scheme of pot experiment}

The experiment was established in the spring in 2013. Seeds of ecotype chosen for experiments were sampled from the calamine population of Gypsophila fastigiata (Caryophyllaceae). Juvenile plants were obtained from seeds sown in greenhouse conditions. A pot experiment, composed of three treatments, was carried on in vegetation hall of University of Agriculture in Krakow. A substratum for plant growth were wastes obtained from $\mathrm{Zn}-\mathrm{Pb}$ flotation tailing ponds of ZGH Bolesław $\mathrm{SA}$ in Bukowno (after flotation enrichment of $\mathrm{Zn}-\mathrm{Pb}$ ores). The following treatments were tested: (1) control untreated waste material (described as CTR); (2) wastes enriched with NPK fertilization applied as $\mathrm{NH}_{4} \mathrm{NO}_{3}, \mathrm{KH}_{2} \mathrm{PO}_{4}$ and $\mathrm{KCl}$ in the dose of $1.2 \mathrm{~g} \mathrm{~N}, 0.4 \mathrm{~g} \mathrm{P}_{2} \mathrm{O}_{5}, 1.0 \mathrm{~g} \mathrm{~K}_{2} \mathrm{O}$ per pot (described as NPK); (3) wastes enriched with sewage sludge coming from the mechanical and biological municipal treatment plant (situated in Krzeszowice, the Province of Małopolska, Poland) in the maximal permissible dose that can be used for reclamation purpose defined by the Ministry of the Environment (Dz. U. $2010 \mathrm{nr} 137$ poz. 924) (described as SS).

Five juvenile plants were planted per pot in six replications. There was evaluated the usefulness of tested species to apply directly in fields delimited on settling pond. The bases of verification were growth rate and some physiological parameters of plant material.

\section{Analytical methods}

During the season (4 and 20 weeks after planting) plants status was evaluated by biometric measurements (mainly plant height, and diameter of specimen) and determining of chosen physiological parameters. The photosynthetic pigments content (chlorophyll $a$, chlorophyll $b$, carotenoids) was ascertained by extraction in acetone and measurement of the extract absorbance at $470 \mathrm{~nm}, 646 \mathrm{~nm}$ and $663 \mathrm{~nm}$ with using UV-Vis spectrophotometer. Next, the pigment concentration was calculated according to Wellburn (1994), and expressed as $\mathrm{mg} \cdot \mathrm{g}^{-1}$ of fresh sample weight. Moreover, the integrity of plasma membrane was tested with the electrical conductivity method based on a modified protocol proposed by Prášil \& Zámečnik (1998), and Kim et al. (2005), with small modifications. $0.2 \mathrm{~g}$ leaf discs of the same diameter were immersed in $20 \mathrm{ml}$ of ultraclean water (Millipore Direct-Q 3 UV with Pump). After 24 hours, the percentage of electrolyte leakage was calculated assuming that $100 \%$ of electrolyte leakage was reached after destruction of biological membranes in $-80^{\circ} \mathrm{C}$. Thus, the highest value of conductivity means the highest injury of the cell.

\section{Statistical analysis}

Biometrical data, the accumulation of pigments, and the integrity of plasma membrane were subjected to ANOVA analysis (STATISTICA, StatSoft, Tulsa, OK, USA). The post-hoc Tukey test was used to study differences between treatments at $\alpha \leq 0.05$, separately for the beginning and the end of growing season (4- and 20-weeks of cultivation, respectively). 


\section{RESULTS}

The growth rate of G. fastigiata in the control pot was inconsiderable. The height and diameter of plants in that treatment did not change significantly with the time (Fig. 1A, B). In contrast, almost twofold increase in the growth was observed in the pot with the addition of sewage sludge. After four weeks of cultivation plants reached about $3.5 \mathrm{~cm}$ of height, and after twenty weeks - about $7.0 \mathrm{~cm}$, whereas the plant diameter increased from $8.4 \mathrm{~cm}$ to $10.3 \mathrm{~cm}$ in those period. In turn, the enrichment of the wastes with NPK, influenced the most a diameter of cultivated plants. At the beginning, value of this feature was similar to the control plants ( $4.6 \mathrm{~cm}$ and $4.5 \mathrm{~cm}$, respectively) but at the end of growing season the diameter of plants of NPK treatment increased by almost $4 \mathrm{~cm}$.

The concentration of photosynthetic pigments in G. fastigiata shoots varied depending on treatment and season. Applied doses of either mineral or organic fertilizers influenced considerably the content of both chlorophyll types as well as carotenoids but differences between these treatments were not statistically significant (Fig. 2A-C). The highest value of chlorophyll $a$ was detected in shoots of plant cultivated on wastes enriched with sewage sludge $-0.78 \mathrm{mg} / \mathrm{g}$ f.w. (Fig. $2 \mathrm{~A}$ ).
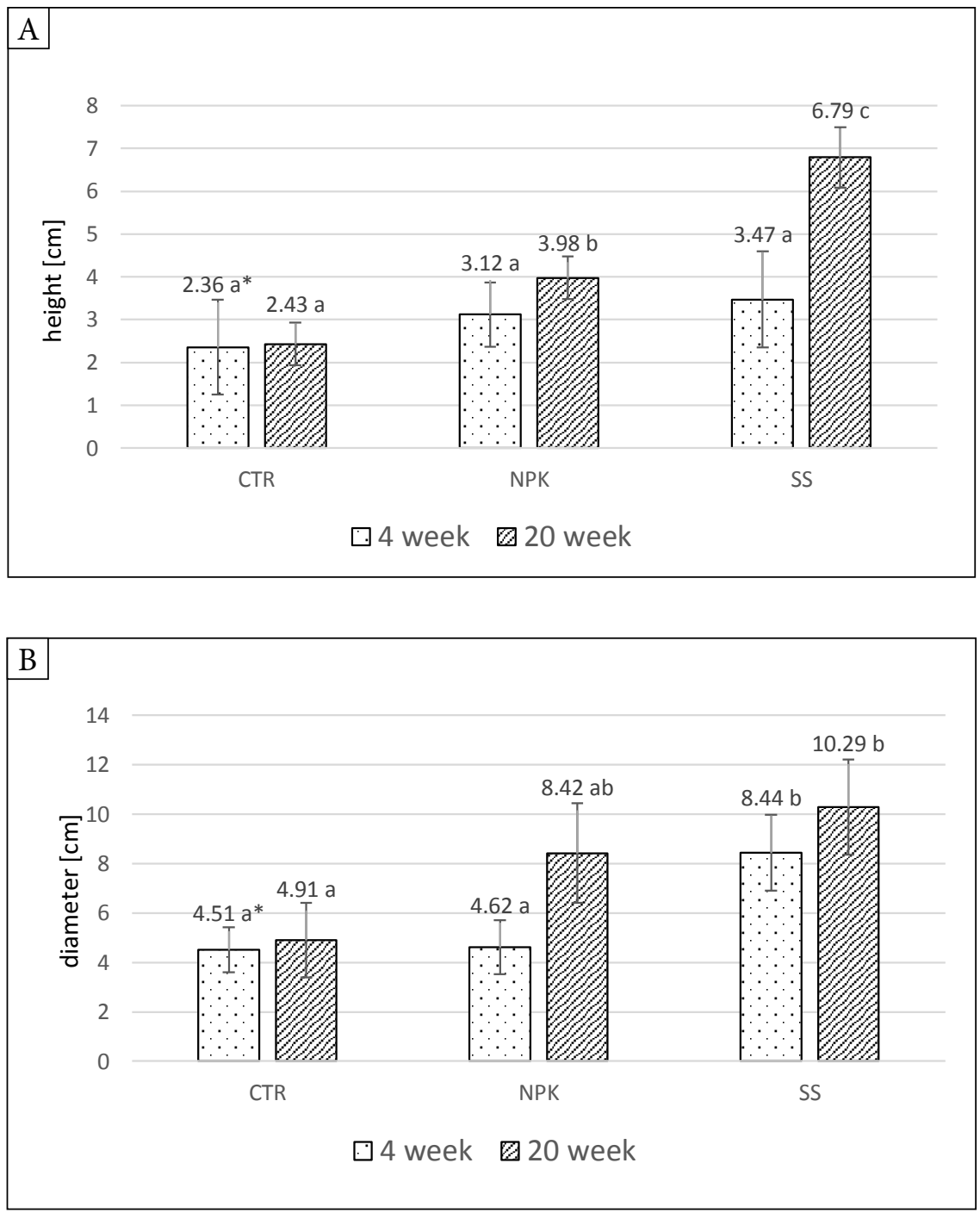

* different letters indicate statistically significant differences at $\alpha=0.05$

Fig. 1. Rate of G. fastigiata growth depending on treatment: A) plant height [cm]; B) plant diameter [cm]; CTR - untreated wastes after $\mathrm{Zn}$-Pb ore flotation, NPK - wastes enriched in NPK fertilization, SS - wastes enriched in sewage sludge) after 4 and 20 weeks of cultivation 

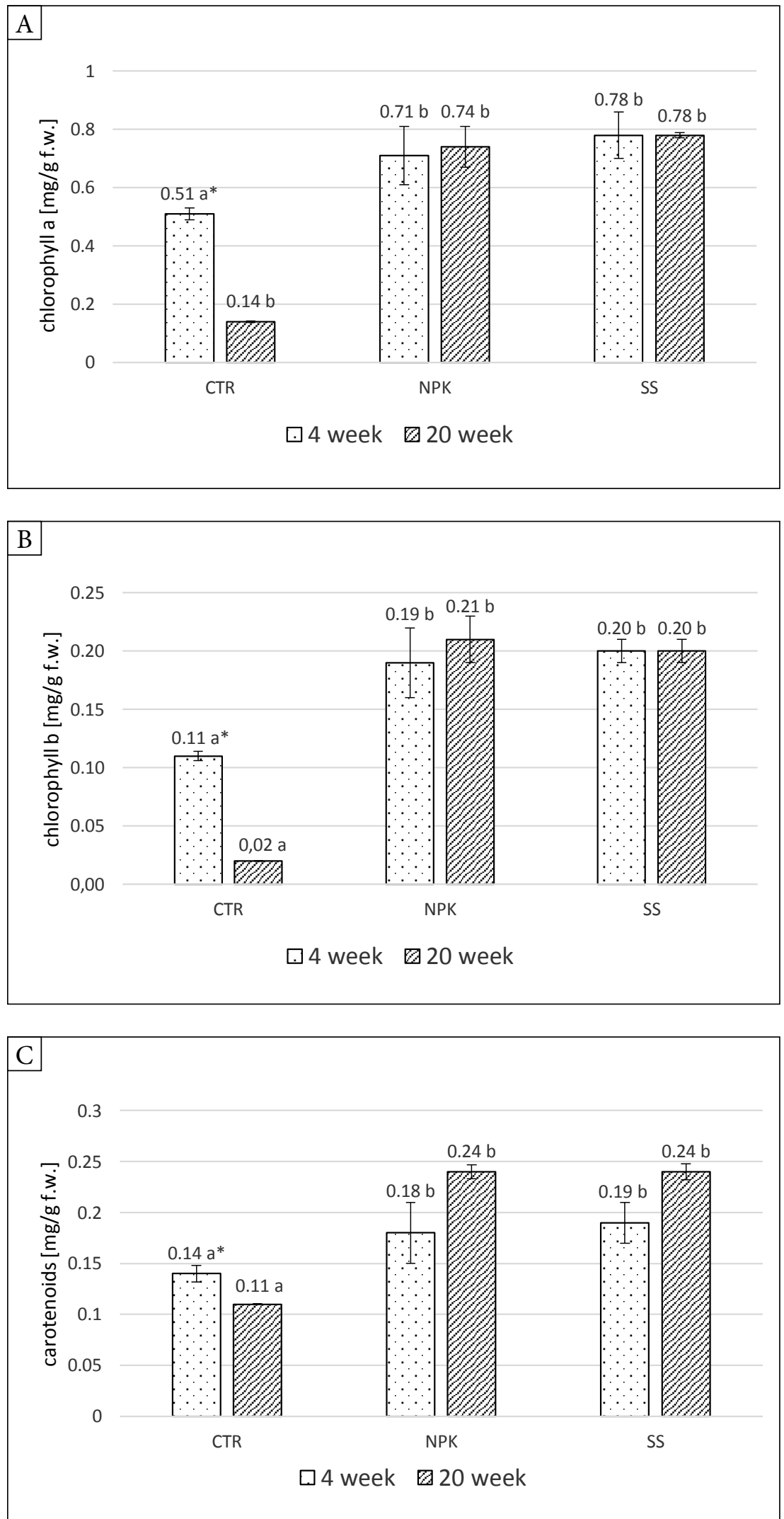

* different letters indicate statistically significant differences at $\alpha=0.05$

Fig. 2. Changes in photosynthetic pigments content [mg/gf.w.] depending on treatment: A) chlorophyll a content; B) chlorophyll b content; C) carotenoids content; CTR - untreated wastes after $Z n-P b$ ore flotation, NPK - wastes enriched in NPK fertilization, SS - wastes enriched in sewage sludge) after 4 and 20 weeks of cultivation 


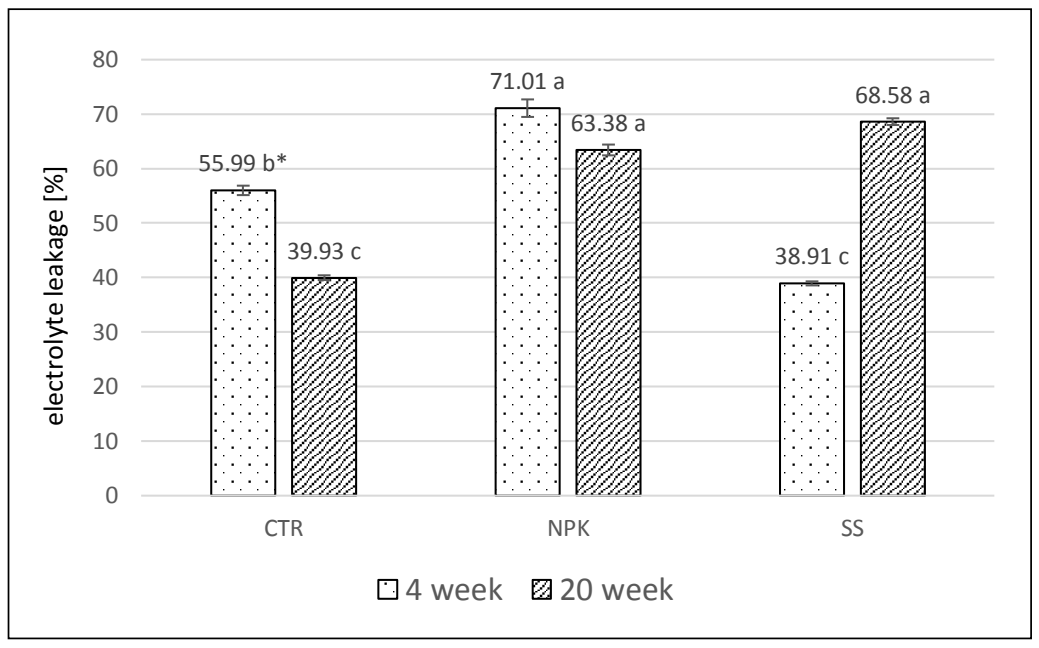

* different letters indicate statistically significant differences at $\alpha=0.05$

Fig. 3. The percentage of the electrolyte leaked outside plasma membrane [\%] depending on the treatment: CTR - untreated wastes after $\mathrm{Zn}$-Pb ore flotation, NPK - wastes enriched in NPK fertilization, SS - wastes enriched in sewage sludge) after 4 and 20 weeks of cultivation

The content of chlorophyll $b$ and carotenoids was quite similar in plants treated with both NPK and SS. The detected value was about $0.20 \mathrm{mg} / \mathrm{g}$ f.w. for chlorophyll $b$ and ranged from 0.18 in the spring to $0.24 \mathrm{mg} / \mathrm{g}$ f.w. in the autumn for carotenoids regardless of the additives (Fig. $2 \mathrm{~B}, \mathrm{C}$ ). Over time, the amount of chlorophyll $a$ and $b$ was at the same level in plants growing on wastes supplemented with sewage sludge $(0.78$ and $0.20 \mathrm{mg} / \mathrm{g}$ f.w., respectively) and increased in plants growing on wastes supplemented with NPK. The most pronounced decrease in all photosynthetic pigment contents was observed in the case of control plants. The amount of chlorophyll $a$ decreased more than threefold, chlorophyll $b$ almost fivefold and carotenoids more than once between the beginning and the end of season (Fig. 2A-C).

The measurements of the electrolyte leakage outside the plasma membrane showed statistically significant differences between experiment treatments (Fig. 3). After four weeks of planting, the highest value of conductivity indicating a damage in more than $70 \%$ of the cells, was measured in plants treated with mineral fertilization. At the same time, the electrolyte leakage caused by the organic treatment reached only $39 \%$. During the season, values of conductivity decreased in plants growing on wastes without any additives, as well as in plants after enrichment of wastes with NPK. On the contrary, plants treatment with sewage sludge resulted in the increase of electrolyte leakage from
$39 \%$ in the spring to $68 \%$ in the autumn. After twenty weeks of cultivation, the lowest value of conductivity linked with membrane integrity loss only in $40 \%$ was observed in control plants (Fig. 3).

\section{DISCUSSION}

It is known that heavy metal pollution has become serious problem in the world due to the consequences of anthropogenic activities and industrialization. These activities can generate large amounts of wastes characterized by extremely unfavorable physicochemical properties and contamination with heavy metals. Extensive efforts have been made to reduce their negative effects on the environment. New, low costs, environmentally friendly and practical approach is to use biological methods. The efficient creation of vegetation cover or acceleration of spontaneous succession rate on mine wastelands may not only stabilize and protect the ground from water and wind erosion, but also restore biological life, and thus prevent further environment contamination (Tordoff et al. 2000, Skubała 2011, Zhang et al. 2014). Therefore, the selection of proper plant material, tolerant to toxic levels of heavy metals and hostile growing conditions, is extremely important issue when metalliferous areas are reclaimed. For this reason, we propose calamine ecotype of $G$. fastigiata as the appropriate plant species to rehabilitation of wastes heaps accumulated after $\mathrm{Zn}-\mathrm{Pb}$ ores flotation. 
Results of previous work carried out in this area showed a high contamination of ground with lead, cadmium and zinc and adverse plant growth condition (Ciarkowska \& Hanus-Fajerska 2008, Szarek-Łukaszewska \& Grodzińska 2008, Muszyńska et al. 2013). This paper highlights the morphological and physiological aspects of examined species in responses to heavy metal contaminated wastes coming from post-flotation settling pond disposed after zinc and lead ore enrichment. The obtained results showed that such material negatively influenced status of plants. The visible symptoms such as: reduction of the plant height and diameter as well as significant decrease in chlorophyll content occurred mainly in plants growing on wastes without any additives. Similar results were observed in vetiver grass grown in heavy metal-containing soil medium. Pang et al. (2003) explained that diminishing content of photosynthetic pigments with increasing proportion of $\mathrm{Pb}-\mathrm{Zn}$ treatment may be due to the inhibition of chlorophyll biosynthesis or accelerated degradation of chlorophyll. This changes lead to the decrease of photosynthesis and thus lower biomass production. Also, Dhir et al. (2011) observed the loss of pigment content in heavy metal exposed plants of Salvinia natans. In this case, the alterations in chlorophyll production occurred as an effect of decrease in availability of ions such as $\mathrm{Fe}$ and $\mathrm{Mn}$ or peroxidation of chloroplast membranes resulting from heavy metal induced oxidative stress (Dhir et al. 2011). Disturbances in photosynthesis were also noticed in many others plants from different families (Küpper et al. 2002, Liu et al. 2004, Mateos-Naranjo et al. 2008, Domínguez et al. 2011). Thus, in order to better understanding the influence of heavy metals on G. fastigiata photosynthetic apparatus efficiency, more parameters should be examined.
Cell membranes are one of the first targets of many plant stresses. Therefore, the simple, inexpensive method useful to evaluate the influence of different environmental factors on plant metabolism, is measurements of the electrolyte leaked outside plasma membrane (Bajji et al. 2001, Chen et al. 2006). For example, it was demonstrated that exposure to mercuric ions disrupted membrane stability in Lycopersicon esculentum (De \& Mukherjee 1996) and the same for cadmium ions in Brassica juncea (Mobin \& Khan 2007). These data correspond with our study. However, a degree of the cellular damage in plants growing on untreated wastes decreased with time what may indicate an easy adaptation of those plants to prevailing conditions. Only G. fastigiata plants treated with sewage sludge showed an increase of electrolyte leakage after twenty weeks of cultivation (Tab. 1). It may be connected with a lack of physiological preparation of plants to winter dormancy and a sudden temperature drop.

The success of biological reclamation depends not only on the careful selection of the plants and amelioration of cultivation conditions, but also on soil amendments. Different agricultural additives favorably influence plants growth, bioavailability of toxic substances and thus can enhance the efficiency of heavy metal removal from the environment (Dede et al. 2012, Li et al. 2013, Nason et al. 2014). The application of sewage sludge is generally considered to be a good option. It offers the possibility of recycling plant nutrients, provides organic material to the soil, and improves the soil properties such as water and air capacity and aggregate stability (Torri \& Lavado 2008). On the basis of analyzed morphological and physiological parameters of G. fastigiata it was demonstrated that enrichment of industrial wastes with mineral

Table 1

The percentage of the electrolyte leaked outside plasma membrane (mean values \pm standard deviation) depending on the season

\begin{tabular}{|c|c|c|c|}
\hline \multirow{2}{*}{ Season } & \multicolumn{3}{|c|}{ Treatment } \\
\hline & CTR $^{*}$ & NPK & SS \\
\hline Spring & $59.99 \mathrm{~b}^{\star *} \pm 0.87$ & $71.01 \mathrm{a} \pm 1.61$ & $38.91 c \pm 0.33$ \\
\hline Autumn & $39.93 c \pm 0.45$ & $63.38 \mathrm{~b} \pm 0.97$ & $68.58 \mathrm{a} \pm 0.66$ \\
\hline
\end{tabular}

* CTR - wastes after Zn-Pb ore flotation, NPK - wastes enriched in NPK fertilization, SS - wastes enriched in sewage sludge,

** different letters indicate statistically significant differences at $\alpha=0.05$. 
as well as organic fertilizers had positive effect on plants conditions. The plant height significantly increased after sewage sludge treatment, while the addition of NPK fertilizers raised tested plants diameter. It could be a result of a high nitrogen content in used amendments. It indicates that the addition of readily available nitrogen was enough to stimulate plant growth even in such harsh conditions. On the other hand, a similar level of photosynthetic pigments during all vegetation season and a lush growth of these plants despite the onset of winter could negatively affect their survival. Therefore, to confirm this assumption, long-term field studies are needed.

\section{CONCLUSIONS}

1. Calamine ecotype of $G$. fastigiata representing flora from Olkusz Ore-Bearing Region may be a good candidate for a biological reclamation of the area polluted with $\mathrm{Zn}$ and $\mathrm{Pb}$.

2. Enrichment of wastes obtained after $\mathrm{Zn}-\mathrm{Pb}$ ores flotation with mineral and organic fertilizers positively influenced the tested plant growth.

3. The highest improvement of plant parameters was observed in the treatment with sewage sludge addition, though their application could have a negative effect on $G$. fastigiata survival during the winter.

The study was supported by Polish Ministry of Science and Higher Education (DS 3500). The financial support is gratefully appreciated.

\section{REFERENCES}

Bajji M., Kinet J.M. \& Lutts S., 2001. The use of the electrolyte leakage method for assessing cell membrane stability as a water stress tolerance test in durum wheat. Plant Growth Regulation, 36, 1, 61-70.

Cabala J., Pacholewska M. \& Dziurowicz M., 2009a. The influence of metalliferous minerals on biotic components of topsoil in $\mathrm{Zn}-\mathrm{Pb}$ flotation tailings ponds. Ecological Chemistry and Engineering A, 16, 7, 723-728.

Cabała J., Krupa P. \& Misz-Kennan M., 2009b. Heavy metals in mycorrhizal rhizospheres contaminated by $\mathrm{Zn}-\mathrm{Pb}$ mining and smelting around Olkusz in Southern Poland. Water Air Soil Pollution, 199, 139-149.

Chen Y., Zhang M., Chen T., Zhang Y. \& An L., 2006. The relationship between seasonal changes in anti-oxidative system and freezeing tolerance in the leaves of evergreen woody plants of Sabina. South Africa Journal of Botany, $72,272-279$.
Ciarkowska K. \& Hanus-Fajerska E., 2008. Remediation of Soil-Free Grounds Contaminated by Zinc, Lead and Cadmium with the Use of Metallophytes. Polish Journal of Environmental Studies, 17, 5, 707-712.

De B. \& Mukherjee A.K., 1996. Mercuric chloride induced membrane damage in tomato cultured cells. Biologia Plantarum, 38, 469-473.

Dede G., Ozdemir S. \& Dede O.H., 2012. Effect of soil amendments on phytoextraction potential of Brassica juncea growing on sewage sludge. International Journal of Environmental Science and Technology, 9, 559-564.

Dhir B., Sharmila P., Pardha Saradhi P., Sharma S., Kumar R. \& Mehta D., 2011. Heavy metal induced physiological alterations in Salvinia natans. Ecotoxicology and Environmental Safety, 74, 1678-1684.

Domínguez M.T., Marańón T., Murillo J.M. \& Redondo-Gómez S., 2011. Response of Holm oak (Quercus ilex subsp. ballota) and mastic shrub (Pistacia lentiscus L.) seedlings to high concentrations of $\mathrm{Cd}$ and $\mathrm{Tl}$ in the rhizosphere. Chemosphere, 83, 1166-1174.

Halim M., Conte P. \& Piccolo A. 2003. Potential availability of heavy metals to phytoextraction from contaminated soils induced by exogenous humic substances. Chemosphere, 52, 1, 265-275.

Janecka B. \& Sobik-Sołtysek J., 2009. Badania przydatności wybranych technik remediacji terenów zdegradowanych działalnością przemysłu cynkowo-ołowiowego. Inżynieria i Ochrona Środowiska, 12, 4, 281-294.

Kim J.G., Luo Y., Tao Y., Saftner R.A. \& Gross K.C., 2005. Effect of initial oxygen concentration and film oxygen transmission rate on the quality of fresh-cut romaine lettuce. Journal of the Science of Food and Agriculture, $85,1622-1630$.

Küpper H., Šetlík I., Spiller M., Küpper F.C. \& Prášil O., 2002. Heavy metal-induced inhibition of photosynthesis, targets of in vivo heavy metal chlorophyll formation. Journal of Phycology, 38, 429-441.

Lamichhane K.M., Babcock Jr. R.W., Turnbull S.J. \& Schenck S., 2012. Molasses enhanced phyto- and bioremediation treatability study of explosives contaminated Hawaiian soils. Journal of Hazardous Materials, 243, 334-339.

Li N., Li Z., Fu Q., Zhuang P., Guo B. \& Li H., 2013. Agricultural Technologies for enhancing the phytoremediation of cadmium-contaminated soil by Amaranthus hypochondriacus L. Water, Air, \& Soil Pollution, 224, 1673-1681.

Liu J., Xiong Z., Li T. \& Huang H., 2004. Bioaccumulation and ecophysiological responses to copper stress in two populations of Rumex dentatus $\mathrm{L}$. from $\mathrm{Cu}$ contaminated and non-contaminated sites. Environmental and Experimental Botany, 52, 43-51.

Mateos-Naranjo E., Redondo-Gómez S., Cambrollé J. \& Figueroa M.E., 2008. Growth and photosynthetic responses to copper stress of an invasive cordgrass, Spartina densiflora. Marine Environmental Research, 66, 459-465.

Mobin M. \& Khan N.A., 2007. Photosynthetic activity, pigment composition and antioxidative response of two mustard (Brassica juncea) cultivars differing in photosynthetic capacity subjected to cadmium stress. Journal of Plant Physiology, 164, 601-610. 
Muszyńska E., Hanus-Fajerska E. \& Ciarkowska K., 2013. Evaluation of seed germination ability of native calamine plant species on different substrata. Polish Journal of Environmental Studies, 22, 6, 1775-1780.

Nason P., Alakangas L. \& Öhlander B., 2014. Impact of sewage sludge on groundwater quality at a formerly remediated tailings impoundment. Mine Water and the Environment, 33, 66-78.

Ospina-Alvarez N., Głaz Ł., Dmowski K. \& Krasnodębska-Ostręga B., 2014. Mobility of toxic elements in carbonate sediments from mining area in Poland. Environmental Chemistry Letters, 12, 435-441.

Panagos P., Borelli P., Meusburger K., van der Zanden E.H., Poesen J. \& Alewell Ch., 2015. Modelling the effect of support practices (P-factor) on the reduction on soil erosion by water at European scale. Environmental Science \& Policy, 51, 23-34.

Pang J., Chan G.S.Y., Zhang J., Liang J. \& Wong M.H., 2003. Physiological aspects of vetiver grass for rehabilitation in abandoned metalliferous mine wastes. Chemosphere, $52,1559-1570$.

Prášil I. \& Zámečnik J., 1998. The use of conductivity measurements method for assessing freezing injury. I. Influence of leakage time, segment number, size and shape in a sample on evaluation of the degree of injury. Environmental and Experimental Botany, 40, 1-10.

Przedpełska E. \& Wierzbicka M., 2007. Arabidopsis areno$s a$ (Brassicaceae) from lead-zinc waste heap in southern Poland - a plant with high tolerance to heavy metals. Plant and Soil, 299, 43-53.

Ravi S., Baddock MC., Zobeck T.M. \& Hartman J., 2012. Field evidence for differences in post-fire aeolian transport related to vegetation type in semi-arid grasslands. Aeolian Research, 7, 3-10.

Rozporządzenie Ministra Środowiska z dnia 13 lipca 2010 r. w sprawie komunalnych osadów ściekowych. Dz. U. 2010 nr 137, poz. 924).

Singh K.L., Sudhakar G., Swaminathan S.K. \& Rao C.M., 2015. Identification of elite native plants species for phytoaccumulation and remediation of major contaminants in uranium taliling ponds and its affected area. Environment, Development and Sustainity, 17, 57-81.
Skubała K., 2011. Vascular flora of sites contaminated with heavy metals on the example of two post-industrial spoil heaps connected with manufacturing of zinc and lead products in Upper Silesia. Archives of Environmental Protection, 37, 1, 57-74.

Soriano-Disla J.M., Gómez I., Navarro-Pedreño J. \& Jordán M.M., 2014. The transfer of heavy metals to barley plants from soils amended with sewage sludge with different heavy metal burdens. Journal of Soils and Sediments, 14, $4,687-696$.

Szarek-Łukaszewska G., 2009. Vegetation of reclaimed and spontaneously vegetated $\mathrm{Zn}-\mathrm{Pb}$ mine wastes in Southern Poland. Polish Journal of Environmental Studies, 18, 4, 717-733.

Szarek-Łukaszewska G. \& Grodzińska K., 2008. Naturalna roślinność w rejonach starych zwałowisk odpadów po górnictwie rud $\mathrm{Zn}-\mathrm{Pb}$ w okolicy Bolesławia i Bukowna (region śląsko-krakowski; południowa Polska). Przegląd Geologiczny, 56, 528-531.

Testiati E., Parinet J., Massiani C., Laffont-Schwob I., Rabier J., Pfeifer H.-F., Lenoble V., Masotti V. \& Prudent P., 2013. Trace metal and metalloid contamination levels in soils and in two native plant species of a former industrial site: Evaluation of the phytostabilization potential. Journal of Hazardous Materials, 248, 249, 131-141.

Tordoff G.M., Baker A.J.M. \& Willis A.J., 20oo. Current approaches to the revegetation and reclamation of metalliferous mine waste. Chemosphere, 41, 219-228.

Torri S.I. \& Lavado R., 2008. Zinc distribution in soils amended with different kinds of sewage sludge. Journal of Environmental Management, 88, 1571-1579.

Wellburn A.R., 1994. The spectral determination of chlorophylls a and b, as well as total carotenoids, using various solvents with spectrophotometers of different resolution. Journal of Plant Physiology, 144, 301-313.

Zhang C., Sale P.W.G., Doronila A.I., Clark G.J., Livesay C. \& Tang C., 2014. Australian native plant species Carpobrotus rossii (Haw.) Schwantes shows the potential of cadmium phytoremediation. Environmental Science and Pollution Research, 21, 9843-9851. 